\title{
Numeracy and Social Justice: A Wide, Deep, and Longstanding Intersection
}

Kira Hamman

Pennsylvania State University, Mont Alto, khh11@psu.edu

Victor Piercey

Ferris State University, VictorPiercey@ferris.edu

Samuel L. Tunstall

Michigan State University, stunstal@trinity.edu

Follow this and additional works at: https://digitalcommons.usf.edu/numeracy

Part of the Applied Statistics Commons, Bilingual, Multilingual, and Multicultural Education Commons, Civic and Community Engagement Commons, Cognition and Perception Commons, Cognitive Psychology Commons, Community-Based Learning Commons, Community-Based Research Commons, Curriculum and Instruction Commons, Curriculum and Social Inquiry Commons, Gender Equity in Education Commons, Inequality and Stratification Commons, Politics and Social Change Commons, Race and Ethnicity Commons, Scholarship of Teaching and Learning Commons, and the Science and Mathematics Education Commons

\section{Recommended Citation}

Hamman, Kira, Victor Piercey, and Samuel L. Tunstall. "Numeracy and Social Justice: A Wide, Deep, and Longstanding Intersection." Numeracy 12, Iss. 1 (2019): Article 2. DOI: https://doi.org/10.5038/ 1936-4660.12.1.2 


\title{
Numeracy and Social Justice: A Wide, Deep, and Longstanding Intersection
}

\author{
Abstract \\ We discuss the connection between the numeracy and social justice movements both in historical \\ context and in its modern incarnation. The intersection between numeracy and social justice \\ encompasses a wide variety of disciplines and quantitative topics, but within that variety there are \\ important commonalities. We examine the importance of sound quantitative measures for understanding \\ social issues and the necessity of interdisciplinary collaboration in this work. Particular reference is made \\ to the papers in the first part of the Numeracy special collection on social justice, which appear in this \\ issue.
}

\section{Keywords}

numeracy, social justice, quantitative literacy, democracy, citizenship

\section{Creative Commons License}

$$
\text { (c) (i) (8) }
$$

This work is licensed under a Creative Commons Attribution-Noncommercial 4.0 License

\section{Cover Page Footnote}

Kira Hamann teaches mathematics at Pennsylvania State University, Mont Alto. A logician by training, she has a longstanding interest in numeracy. Her current work focuses on the intersections between mathematics, quantitative literacy, and social justice.

Samuel Luke Tunstall is a doctoral candidate in mathematics education and University Distinguished Fellow at Michigan State University. His research interests include quantitative literacy and the sociology of education.

Victor Piercey is an associate professor in the mathematics department at Ferris State University. He is interested in using his legal experience to enhance his mathematics instruction and provide students with transformative experiences. His current project is an inquiry-based sequence of courses entitled Quantitative Reasoning for Professionals. 
The numeracy movement has been integrally related to issues of social justice since its infancy. This year marks the sixtieth anniversary of the Crowther Report, which coined the very term numeracy and decried the fact that "the available resources of [people] of high ability are not fully used by the present system... Of course, there is a close association between the facts of under-utilised ability... and the facts of under-represented social groups" (Crowther 1959, 8). Just over twenty years later, in 1982, civil rights movement veterans Robert Moses and Charles Cobb recognized that "the ongoing struggle for citizenship and equality for minority people is now linked to an issue of math and science literacy" (Moses and Cobb 2001, 14). Specifically, they believed that the lack of access to middle-school algebra for many minority students contributed to the continued lack of social and economic equity, and Moses used his MacArthur Fellowship to launch the pioneering Algebra Project.

Sadly, this "ongoing struggle" continues into the twenty-first century. By virtually any meaningful measure-standardized test scores, high school graduation rates, college access, employment status, median income-quantitative literacy is still undeniably correlated to success. Furthermore, the same social, racial, and economic groups continue to be underrepresented among the successful. Why? What can we do about it? And how do we convince all stakeholders that quantitative literacy is empowering?

The purpose of this collection is to provide a forum to address those issues through scholarship and pedagogy, and to reflect on the intersection between numeracy and social justice. As the variety of papers in the collection makes evident, that intersection is wide and it is deep, encompassing fields ranging from economics to history to sociology. The quantitative topics touched on are equally diverse: probability and statistics, mathematical modeling, and methods of measurement, among others.

"Mississippi Semester: New Social Justice Approach to Teaching Empirical Reasoning in Context," describes a novel experiential learning course at Barnard College. In this paper, Premilla Nadasen, Fatima Koli, Alisa Rod, and David Weiman share with readers their experience facilitating a campus-community collaboration through a course entitled "Mississippi Semester: Child Care, Race, and the History of Welfare." Here, we learn about the challenges and successes the authors and their colleagues, students, and community partners encountered as they attempted to develop an economic (in)security index for women in a low-income community in Mississippi.

In "Brave Spaces: Augmenting Interdisciplinary STEM Education by Using Quantitative Data Explorations to Engage Conversations on Equity and Social Justice," two veteran STEM educators at the University of Delaware-John Jungck and Jon Manon - report on their experiences hosting interdisciplinary workshops with in-service high school teachers. The topics in those workshops included 
China's one child policy and slave breeding during the U.S. pre-Civil War period; both were examined through a quantitative lens, with the unifying theme being that the topics centered on population growth and social justice. In this article, the authors provide readers not only with an exposition of the topics themselves and the associated quantitative explorations, but also with a rich discussion of the ways teachers engaged with the themes - themes that Jungck and Manon say some might consider "taboo."

In "The Gini Index: A Lens for Analyzing Inequality in an Interdisciplinary College Classroom," Jared Warner and Vivian Lim describe and reflect on an interdisciplinary teaching module in a course that integrates numeracy with reading and writing. The authors' module is built around the Gini index, a quantitative tool used to measure inequality in resource allocation. Here it is used to measure and compare income inequality, a key social justice concern, at different geographic scales. The authors' module explicitly addresses the need for other measures to triangulate one's conclusions. At a deeper level, the authors reflect on their work using a framework adapted from culturally responsive pedagogy, which includes teaching practices designed to promote equitable classrooms. This is certainly an important concern for those seeking to teach for socially just purposes.

Finally, in "Social Justice, Numeracy, and Teaching Statistics at a Community College," Edward Volchok describes his experiences teaching statistics to business students at a diverse, urban community college and offers some lessons learned. Volchok's students are acutely aware of social injustice, which many of them experience in their own lives, and he posits that this makes them prime candidates for quantitative literacy education. He reflects on the connections between numeracy and educational, political, and social equity and, as someone coming from a political science background, explores what the concept of "justice" means in connection with numeracy.

Diverse as the collection is, there are also strong common threads throughout the papers. This suggests that certain aspects of numeracy are more central to questions of social justice than others, and little is more central than the need for meaningful measures. The critical role of measurement in understanding social phenomena is apparent in Warner and Lim's exploration of the Gini index and in the development of an economic insecurity measure in Nadasen et al. Both point out that the measurement process is subtle. The modeler must decide what is important and what assumptions are reasonable. Even in the best of circumstances, multiple measures need to be triangulated and may tell conflicting stories. Normative issues are inherent to social justice questions, but as several authors in the collection point out, quantification can create common ground to help work through the inevitable points of contention. At the same time, as Joel Best notes in his review of Jerry Muller's The Tyranny of Metrics in the Summer 2018 issue of this journal, metrics can also be abused to "game the system" (Best 2018, 2). This 
modern version of the old adage about lies and statistics, which Volchok discusses in this issue, points out the ongoing need to guard against the risk of measurement becoming a pitfall, fraught with its own social and political ramifications.

The centrality of interdisciplinary collaboration is also evident across the collection, as it is in our professional community more broadly. Social justice issues are never contained within a single discipline, and thus our approach to addressing them can't be either. Interdisciplinary collaboration enabled Nadasen et al. to create a space for developing an economic insecurity metric. Warner and Lim describe integrating reading and writing with numeracy in their course. The workshops Jungck and Manon have created are by their very nature interdisciplinary. The contributors to this collection include faculty in business, economics, biology, geology, geography... the list is long. The interdisciplinarity at the heart of numeracy makes it a natural partner in the ongoing work of social justice.

Not only does 2019 mark sixty years since the emergence of numeracy and innumeracy as social justice issues, this month marks ninety years since the birth of Martin Luther King, Jr. "The arc of the moral universe is long," Dr. King memorably said, "but it bends toward justice" (King 1964). We believe that numeracy lies along that arc and hope that this collection will help bend it in the right direction.

\section{Acknowledgments}

Our deepest gratitude goes to Executive Editor Nathan Grawe, without whose unflagging confidence and gentle nudges this collection would not have happened, and to Senior Editor Len Vacher, whose sharp insights are often witty and always spot on. We also sincerely thank all of the authors in the collection, whose patience with us as editors we tested frequently but never managed to exhaust. Their hard work and thoughtful contributions to a very important conversation are inspiring. Finally, we are grateful to our institutions for supporting us in this work.

\section{References}

Best, Joel. 2018. "Numbers Games: Review of The Tyranny of Metrics by Jerry Z. Muller (2018)." Numeracy 11(2): Article 13. https://doi.org/10.5038/19364660.11.2.13.

Crowther, Geoffrey. 1959. The Crowther Report. A Report of the Central Advisory Council for Education (England). London: Her Majesty's Stationery Office.

King Jr., Martin Luther. 1964. Wesleyan Baccalaureate. Sermon given at Wesleyan University commencement exercises. Middletown, CT. 
Numeracy, Vol. 12 [2019], Iss. 1, Art. 2

Moses, Robert P., and Charles E. Cobb Jr. 2001. Radical Equations: Math Literacy and Civil Rights. Boston: Beacon Press.

Muller, Jerry Z. 2018. The Tyranny of Metrics. Princeton, NJ: Princeton University Press. https://doi.org/10.23943/9781400889433. 